\title{
URGENSI IINTEGRASI NILAI LOCAL WISDOM DALAM KONFLIK SUPORTER SEPAKBOLA
}

\author{
Pujiyono dan Mulyanto \\ Fakultas Hukum Universitas Sebelas Maret Surakarta \\ e-mail: satryo_solo@yahoo.com,sheemoel@yahoo.com
}

\begin{abstract}
This study was conducted to describe the factors that cause conflict among football fans. There are findings of two (2) factors causing conflict football supporters that internal factors are derived from the self-supporters and external factors outside themselves supporters as unfair referee; conditions of players, and conditions in the field as revenge of the past, the movement spontaneous, mutual blasphemy and provocateur. In an academic perspective, need to be developed integrating the values of local wisdom in preventing conflict between supporters of football, including the proverbial "win without ngasorake". If supporters uphold these values, conflict and reduced football fans are increasingly aware of the importance of maintaining fair play.
\end{abstract}

Keywords: integration, local wisdom, football

\begin{abstract}
Abstrak
Penelitian ini dilakukan untuk menjelaskan faktor-faktor yang menyebabkan konflik antar suporter sepakbola. Ada temuan terdapat 2 (dua) faktor penyebab konflik supporter sepak bola yakni faktor internal yang berasal dari dalam diri supporter dan faktor eksternal yang berasal dari luar diri supporter seperti Wasit yang tidak adil; Kondisi pemain; dan Kondisi di lapangan seperti dendam masa lalu, gerakan spontan, saling hujat dan provokator. Dalam perspektif akademis, perlu dikembangkan pengintegrasian nilai-nilai local wisdom dalam mencegah konflik antar suporter sepakbola, diantaranya pepatah "menang tanpa ngasorake". Apabila suporter menjunjung tinggi nilai tersebut, konflik suporter sepakbola berkurang dan semakin sadar pentingnya menjaga fair play.
\end{abstract}

Kata kunci: integrasi, kearifan lokal, sepakbola

\section{A. Pendahuluan}

Indonesia merupakan negara hukum yang memiliki keanekaragaman budaya di setiap daerahnya, tak terkecuali olahraga sepakbola. Sepakbola yang merupakan olahraga terpopuler di dunia, juga banyak di minati oleh para penduduk Indonesia. Tak dapat dipungkiri, di Indonesia memiliki ratusan atau bahkan ribuan klub sepakbola mulai dari tingkatan rendah hingga tingkatan tinggi macam Persipura, Arema, Persija, Persib dan sebagainya. Dalam pertandingan Sepakbola tidak dapat lepas dari peran suporter yang sering disebut pemain kedua belas dari tim kesebelasan (Dekama, 2011: 1). Artinya, kehadiran supporter sebagai pemain keduabelas yang memberikan semangat pada tim kesayangannya (Muamar Kadafi, 2011: 7). Bahkan, kehadiran supporter di lapangan, semakin menambah tontonan yang menarik dan ragaan yang atraktif.

Namun ironisnya, kehadiran suporter Sepakbola sering berbanding terbalik dengan sportivitas pertandingan. Aroma persaingan antar suporter pun acapkali mewarnai perjalanan panjang persepakbolaan Indonesia, rivalitas antar suporter hingga menimbulkan konflik antar suporter selalu terjadi di persepakbolaan tanah air (Fajar Junaedi, 2011: 2). Konflik suporter bukan saja merusak fasilitas di dalam stadion, namun juga diluar stadion bahkan sampai ada yang meninggal dunia. Pada 27 Mei 2012, konflik supporter Persija (The Jack) dengan supporter Persib Bandung (Bobotoh) di Jakarta mengakibatkan 3 (tiga) orang meninggal dunia yakni Lazuari, Dani Maulana, dan Rangga Cipta Nugraha (Kompas, 28/5/2012). Akhirnya, Federasi Sepak bola Asia (AFC) menjatuhkan sanksi berupa denda sebesar sebesar USD15.000 atau setara Rp146 juta kepada PSSI terkait ulah suporter Indonesia.

Baru-baru ini terjadi kericuhan antar supporter Persis Solo dengan supporter PSS Sleman di Stadion Manahan Solo. Sejak awal Suasana pertandingan sudah tegang, pendukung Persis Solo atau yang lebih dikenal dengan sebutan 
Pasoepati memenuhi tribun selatan, tribun utara, dan tribun barat terus meneror pemain PSS Sleman. Sepanjang babak pertama, berulang kali ada lemparan botol air mineral dan petasan ke tengah lapangan. Bahkan Pasoepati juga mengancam akan membakar bus PSS Sleman. Kejadian itu, tujuh penonton menjadi korban pemukulan pendukung Persis Solo (Solopos, 5/9/2013).

Berdasarkan realita pergeseran perkembangan supporter yang ke arah negatif seharusnya mendapat perhatian yang lebih serius dari segenap pihak. Muncul pertanyaan mendasar mengapa Solo sebagai kota budaya yang berslogan "The spirit of Java" mudah tersulut kerusuhan suporter sepakbola? Bukankah seyogyanya suporter pasoepati santun dalam mendukung tim Persis Solo maupun dalam menyambut kedatangan suporter tim lawan. Kota Solo dikenal banyak memiliki budaya luhur dan nilai-nilai kearifan lokal (local wisdom). Oleh karena itu, artikel ini membahas tentang integrasi nilai-nilai local wisdom sebagai upaya mencegah konflik antar supoter sepakbola.

\section{B. Metode Penelitian}

Dalam penelitian ini digunakan metode sosiolegal. Studi sosiolegal merupakan kajian terhadap hukum dengan menggunakan pendekatan ilmu hukum maupun ilmu sosial (Sulistyowati Irianto dan Shidarta, 2009: 174). Penelitian ini menggunakan pendekatan penelitian kualitatif. Penelitian ini berlokasi di Surakarta dengan menggunakan data primer maupun data sekunder. Data primer diperoleh dari Narasumber Pengurus Pasoepati, budayawan maupun Suporter Pasoepati. Data sekunder diperoleh dari hasil penelaahan literatur yang berkaitan dengan materi penelitian (Mukti Fajar ND dan yulianto Achmad, 2010: 156). Data sekunder terdiri bahan hukum primer bahan hukum sekunder berupa buku, makalah, data internet, dan bahan hukum tersier. Instrumen pengumpulan data dengan cara wawancara mendalam (indepth interviewing) dan studi dokumen (William L Neuman, 2006: 71). Teknik analisis data secara kualitatif dengan menggunakan theoritical interpretative, yaitu analisis dengan jalan memberikan penafsiran terhadap data yang dikumpulkan dengan mendasarkan pada landasan teori sebagai kerangka berpikir atau sebaliknya.

\section{Hasil Penelitian dan Pembahasan \\ 1. Faktor-faktor Penyebab Konflik Suporter Sepakbola}

Dalam kehidupan bermasyarakat kita selalu di hadapkan dengan berbagai macam masalah atau konflik. Konflik dalam kehidupan pasti selalu ada dan tidak dapat di hilangkan (Bambang Sugeng, 2011: 1). Konflik hanya dapat dicegah agar masalah yang timbul tidak semakin besar dan parah. Konflik dilatarbelakangi oleh perbedaan ciri-ciri yang di bawa individu dalam suatu interaksi. Contohnya, dalam dunia olahraga khususnya sepakbola kita sering sekali melihat konflik di dalamnya, baik itu antara pemain, wasit, atau antar suporter kedua kesebelasan. Dalam sepakbola konflik merupakan keniscayaan karena pada dasarnya sepakbola merupakan olahraga yang didalamnya terdapat upaya untuk mengalahkan pihak lawan untuk memperoleh kemenangan.

Suporter yang terlibat langsung dengan tim yang bertanding ikut terseret dalam situasi konflik tersebut. Suporter hadir di arena pertandingan dengan tujuan mendukung untuk menaikkan mental dan moral tim yang didukung sekaligus meneror mental tim lawan. Ketika dua kelompok suporter bertemu di arena pertandingan dengan tujuan yang sama namun berbeda tim yang didukung maka yang terjadi adalah pertentangan, perang yel-yel, saling ejek dan lain-lain. Dengan demikian secara umum konflik merupakan aktualisasi dari suatu perbedaan dan pertentangan antara dua pihak atau lebih.

Para suporter di Indonesia memang patut dihargai dalam mendukung tim kesayangan mereka. Mereka mempunyai rasa fanatik yang besar bagi tim kesayangannya. Tetapi, fanatisme itu tidak selalu berbuah positif. Fanatisme yang berlebihan ini bisa menimbulkan sifat anarkis yang bisa mengakibatkan tawuran terjadi antar suporter. Tawuran yang terjadi biasanya diakibatkan oleh suporter yang tidak rela melihat tim kesayangan kalah dari tim lain. Suporter seperti inilah yang bisa merugikan persepakbolaan Indonesia dan meresahkan masyarakat karena ulah mereka.

Faktor-faktor terjadinya konflik antar suporter sepakbola bervariasi. Hal tersebut diperoleh dari data empiris yang telah penulis dapatkan dari hasil wawancara dengan pengurus Pasoepati maupun hasil kuesioner. Ternyata terdapat 2 (dua) faktor penyebab konflik antar supporter yakni faktor internal dan faktor eksternal. Faktor internal merupakan faktor yang berasal dari dalam diri supporter yang dapat dijabarkan sebagai berikut: 
Pertama, Sikap yang belum dewasanya supporter. Sikap suporter yang belum dewasa dapat diartikan sebagai mental suporter yang buruk. Suporter terkadang sulit menerima jika tim yang didukungnya mengalami kekalahan dan suporter yang tak memiliki mental baik kemungkinan akan melampiaskan kepada hal - hal yang berada diluar sportivitas. Mental bertanding tidak cukup hanya dimiliki oleh pemain saja, semua elemen di sepakbola harus memiliki mental baja. Kedua, ingin menunjukan eksistensinya kepada kelompok suporter lain. Namun tak sedikit yang melakukannya dengan cara yang tak lazim, misalnya dengan menyanyikan yel-yel hujatan terhadap suporter lain ataupun melalui sebuah karya yang menjadi identitas suporter tersebut. Inilah awal permusuhan antar suporter yang terjadi di Indonesia. Berikutnya, suporter terkadang hanya sekedar tahu tentang sepakbola. Terkadang mereka merasa paling benar dan paling tahu tentang peraturan permaianan sepakbola, padahal peraturan permainan sepakbola itu selalu berkembang. Ketidak pahaman akan peraturan ini pula yang dapat menimbulkan kerusuhan yang dilakukan suporter. Belum lagi hal ini selalu diperparah oleh sikap suporter yang tidak terdidik yang selalu mengotori lapangan dengan sampah dan batu ketika mereka merasa tidak puas dengan apa yang terjadi di lapangan. Kemudian, tingkat intelegensi dan pengetahuan suporter di Indonesia pun harus dipertanyakan. Jika mereka tahu bahwa sepakbola terdapat nilai-nilai positif yang bisa meredam permusuhan di dalamnya, tidak akan ada pertikaian yang terjadi.

Kedua, Suporter yang konsumsi minuman keras. Suporter sepak bola sebagian besar didominasi oleh para pemuda yang memiliki jiwa militan sangat kuat. Namun dalam segi mensuport kesebelasannya keadaan yang sangat memungkinkan untuk menciptakan tindakan yang diluar dugaan adalah cara sebagian suporter yang di jelaskan di atas sebagai provokator dengan mengkonsumsi narkoba dan minuman keras dalam area pertandingan sepak bola yaitu didalam stadion. Dikarenakan banyaknya suporter yang terdapat di suatu arena menyebabkan semakin amannya pemakaian barang haram tersebut. Kostum yang hampir menyerupai dan dalam kondisi yang sangat bersemangat maka tak jarang penyalahgunaan keadaan lantas dijadikan sebagai sarana untuk pengonsumsian barang tersebut.

Dalam pandangan KRHM Satrio Hadinegoro (Kanjeng Satrio), selaku mantan Presiden Pasoepati pada Periode 2002 2004, (wawancara tanggal 21 September 2013) bahwa faktor penyebab timbulnya atau terpicunya konflik antar supporter karena ada provokator dan jelas itu karena minuman keras. Setiap pertandingan itu pasti ada bawa atau minum minuman keras. Sewaktu masa Kanjeng Satrio, ada Pandega, yaitu polisi atau provos yang menjaga suporter Pasoepati. Pandega itu yang sweeping. Sekarang, saya rasa sudah tidak ada. Jadi Padega itu tugasnya yang menjaga disiplin supporter. Mereka itu yang melakukan sweeping ke supporter kita, baik sweeping minuman keras, bawa senjata tajam, atau biar supporter tidak bludus (masuk stadion tanpa bayar tiket). Biasanya Pandega itu kita ambil dari korwilkorwilnya. Biar korwilnya bisa mengatur supporter dari wilayahnya. Saya lihat akhirakhir ini tidak seperti ini, agak disayangkan.

Bahkan mudah sekali akses dalam mendapatkan barang tersebut, karena dapat langsung dibeli di dalam stadion dan cara pendistribusiannya ternyata sangat mudah sekali karena dilakukan dari mulut ke mulut dengan catatan antar anggota suporter. Dari beberapa orang yang kerap menggunakan barang ini di stadion sudah menjadi hal yang wajar. Mendukung tim kesayangan memerlukan performance yang ekstra dan juga membutuhkan ekspresi yang berlebihan sepanjang 90 menit pertandingan berlangsung, membawakan lagu dan gerakan tubuh yang di pandu oleh konduktor demi mendukung tim kesayangan berlaga. Bahkan Sekjen Pasoepati, bapak Anwar Sanusi berpendapat bahwa mengkonsumsi minuman keras tersebut adalah agar dapat menyanyi secara lantang dan dapat dengan total memberikan dukungan untuk Persis Solo.

Ketiga, Tingkat pendidikan. Fanatisme berlebihan terhadap tim sepakbola kadang bisa mengarah ke tindakan anarkistis. Psikolog sosial dari Universitas Airlangga, Surabaya, Ahmad Chusairi, menilai perilaku fanatik suporter sepakbola Indonesia dilatarbelakangi sejumlah faktor. Di antaranya, ekonomi, pendidikan, dan budaya suporter itu sendiri. Faktor pendidikan salah satu faktor yang menyebabkan kerusuhan suporter karena tingkat pendidikan para suporter berbeda-beda mengingat pendidikan 
pelakunya tidak bisa dideteksi secara jelas, mengingat tidak ada tanda-tanda atau atribut yang mendukungnya. Semakin tinggi tingkat pendidikan seseorang semakin baik tingkat kesadarannya dan semakin rendah seseorang maka tingkat kesadarannya kurang. Tingkat pedidikan seorang suporter juga mempengaruhi tingkah laku dalam mendukung tim kesayangannya.

Berdasarkan hasil kuesioner yang telah diedarkan terhadap Suporter Pasoepati dapat diperoleh data di bawah ini.

diagram Pendidikan Terakhir Pasoepati Solo

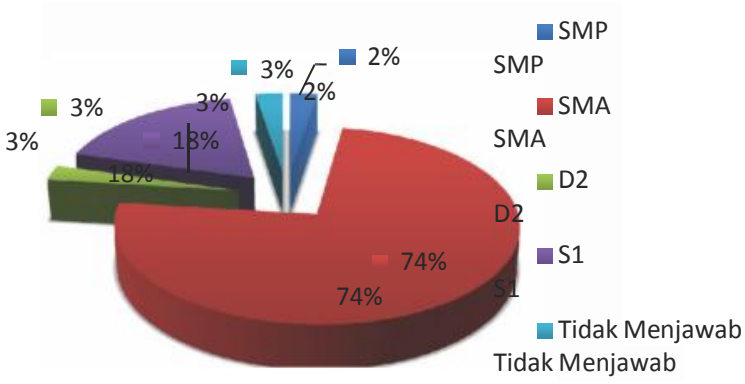

Dari diagram tersebut di atas dapat diketahui bahwa pendidikan terakhir Suporter Pasoepati Solo dapat dideskripsikan sebagai berikut. Mayoritas berpendidikan Sekolah Menengah Atas (SMA). Hal tersebut dapat diketahui sebesar $74 \%$ supporter yang berpendidikan SMA, Selanjutnya yang berlatar belakang pendidikan Sekolah Menengah Pertama (SMP) sebanyak $18 \%$, sedangkan untuk pendidikan Diploma (D) sama dengan yang berpendidikan Sarjana (S1) yakni sebesar $3 \%$. Adapun yang tidak menjawab kuesioner yang telah dibagikan sebsara $2 \%$. Dengan demikian dapat disimpulkan bahwa mayoritas pendidikan Pasoepati yakni berlatar belakang SMA.

Keempat, Sifat massa yang tersulut kemarahan akan mudah sekali diikuti teman lainnya. Fanatisme adalah keyakinan atau kepercayaan yang terlalu kuat terhadapsuatu ajaran baik itu politik, agama dan sebagainya, dalam penelitian ini dikaitkandengan fanatisme terhadap klub sepakbola. (Sudirwan,1988). Chaplin (1997) mengartikan motivasi sebagai suatu energi yang mengorganisasi perilaku secaraterpelihara, terarah pada tujuan tertentu yang ditimbulkan oleh suatu ketegangandalam diri individu sebagai faktor penggerak dari organisme. Jika dihubungkandengan penelitian ini, maka energi yang mengorganisasi perilaku suporter tersebut diarahkan hanya untuk memberikan dukungannya terhadap satu klub sepakbola saja.

Fanatisme erat sekali hubungannya dengan rasa kecintaan terhadap klub sepak bola favorit suporter tersebut. Maraknya aksi kerusuhan suporter yang melibatkan sebagian manusia dikarenakan manusia tidak ingin melihat kekuasaannya dicabik - cabik. Kecintaan terhadap klub adalah faktor dari semua ini. Kondisi ini pula lah yang terjadi pada kelompok atau organisasi suporter sepakbola, dimana mereka saling bersatu padu untuk melindungi anggotanya dari serangan suporter lain. Sebuah kecintaan yang berlebih, itulah gambaran sederhana tentang fanatisme. Sehingga rasa saling memiliki yang berlebihan inilah yang sangat memungkinkan tersulut kemarahan dan dapat dengan mudah diikuti oleh teman sesama suporter.

Kelima, Anak-anak muda yang masih menonjolkan sisi emosional dan masih labil. Seperti yang dikatakan oleh bapak sekjen Pasoepati yakni dapat disimpulkan bahwa keanggotaan dalam Pasoepati sebagian besar anggotanya masih tergolong anak-anak muda yang masih menonjolkan sisi emosional dan masih labil. Berdasarkan hasil kuesioner yang telah diedarkan terhadap Pengurus Pasoepati dapat diperoleh data bahwa alasan tawuran karena diejek supporter lawan sebanyak $14 \%$, sedangkan penyebab tawuran karena membela teman lebih banyak yakni $25 \%$, sedangkan alas an lain-lain sebanyak $61 \%$. Adapun prosentase dari suporter yang pernah ikut tawuran lebih banyak daripada yang belum pernah terlibat tawuran (konflik) supporter yakni sebanyak 54 \%dan 46 \%. Artinya memang di lapangan rasa emosional supporter akan lebih mudah tersulut, meskipun dipicu oleh berbagai faktor. Hal tersebut terbuktidari lebih banyaknya pengurus Pasoepati yang pernah terlibat konflik daripada yang tidak pernah terlibat.

Adapun faktor eksternal merupakan faktor yang berasal dari luar diri supporter, yang dapat dijabarkan sebagai berikut.

Pertama, Wasit yang tidak adil. Wasit yang tidak adil menjadi penyebab terjadinya konflik antar suporter sepak bola. Wasit adalah seorang yang memimpin jalannya pertandingan. Karakter wasit yang tegas dan tidak memihak sangat diperlukan dalam suatu pertandingan. Selain itu, wasit juga tidak boleh plin plan dalam membuat keputusan. Di Indonesia, kepemimpinan wasit biasanya 
diduga sebagai pencetus amarah suporter yang bisa membuat tawuran antar suporter ini bisa terjadi. Banyak pertandingan di liga Indonesia diberhentikan pada saat pertandingan berlangsung dan salah satu penyebabnya adalah amukan suporter yang tidak bisa dihentikan karena menurut mereka wasit yang bertugas tidak adil dalam memimpin pertandingan. Dalam suatu pertandingan, suporter harus bisa menerima segala keputusan wasit karena wasit lebih mengerti apa yang seharusnya dilakukan tetapi wasit juga harus teliti dan tegas dalam memimpin suatu pertandingan agar kejadian seperti tawuran ini tidak terjadi. Kita mengerti bahwa menjadi seorang wasit tidaklah mudah.

Kedua, Kondisi pemain. Faktor kematangan emosi menjadi penyebab buruknya permainan. Bagi pemain yang belum bisa mengontrol emosi. Untuk mencetak gol, bola ditendang kencang atau pelan sama saja, yang penting terarah menurut Manajer PSS Sleman, Rumadi dalam web resmi Slemania, agar bola dapat dengan indah masuk ke dalam gawang. Sebaliknya, pemain yang memiliki kematangan dari sisi emosi akan dapat mampu mengontrol permainan.

Ketiga, Kondisi di lapangan. Kondisi di lapangan dapat didefinisikan sebagai faktor terbanyak yang muncul dari berbagai penyebab konflik yang dapat pula berupa muatan dendam masa lalu baik klub maupun suporter, gesekan spontan di lapangan / tribun, efek koordinator - koordinator yang provokatif, efek dari hasil pertandingan dan provokasi dari dalam lapangan baik yang di lakukan oleh pemain, ofisial dan wasit.

Dalam pandangan pak anwar sanusi Bapak Anwar Sanusi, selaku Sekjen Pasoepati 2009-2013, (wawancara tanggal 23 September 2013) mengatakan bahwa yang menjadi faktor timbulnya atau terpicunya konflik antar supporter di dasarkan pada pengalamannya selama 13 tahun ini. Faktor yang menimbulkan gesekan antar suporter dikarenakan dari pertandingan di lapangan. Saling hujat dan menghina antarsuporter di setiap pertandingan itu justru akan semakin memupuk rasa dendam. Jika itu terus dilakukan, rasanya sulit untuk mengikis kekerasan dan kerusuhan dalam sepak bola. Faktor wasit yang tidak adil dan juga faktor pemain juga termasuk di dalam faktor ini.

2. Identifikasi Nilai-nilai Local Wisdom Dalam Mencegah Konflik Antar Suporter Sepak Bola
Konflik merupakan suatu gejala yang sangat umum dan begitu sering muncul sebagai akibat dari interaksi manusia dalam hidup bermasyarakat. Setiap ada interaksi dalam masyarakat akan berpotensi menimbulkan konflik (J. Dwi Narwoko dan Bagong Suyanto: 2007: 70). Terdapat tiga model penjelasan yang dapat dipakai untuk menganalisis kehadiran konflik dalam kehidupan masyarakat, pertama penjelasan budaya, kedua, penjelasan ekonomi, ketiga penjelasan politik (Pheni Chalid, 2005:107108).

Konflik yang bersumber pada ketidakadilan dapat dicarikan alternative solusinya, salah satunya melalui local wisdom. Budaya jawa yang masih dijadikan pedoman hidup masyarakat Jawa memiliki banyak nilai-nilai local wisdom yang dapat dikaji dan difungsikan dalam pencegahan konflik supporter sepakbola. Berdasarkan hasil wawancara dengan budayawan, Ibu Insiwi Febriary Setiasih, S.S.,M.A. pada hari Jumat, 6 September 2013 di Gedung III bagian Sejarah Fakultas Sastra dan Seni Rupa Universitas Sebelas Maret mengatakan bahwa Local wisdom atau kearifan lokal merupakan kekayaan yang dapat berupa ide, gagasan, tindakan, kebiasaan yang tidak ditemukan di tempat lain serta barang yang kesemuanya itu dimiliki oleh masyarakat tertentu. Contoh dari kebiasaan yang tidak ditemukan di tempat lain ialah bahasa di Jawa yang bertingkat-tingkat penerapannya, hal ini berimplikasi terhadap karakteristik dari orang Jawa menghargai segala usia.

Selain yang telah disebutkan tadi, ada pula suatu local wisdom yang berupa tradisi wiwitan di dalam tanam-menanam yakni sebagai bentuk komunikasi petani dengan alam. Kemudian pola interaksi juga merupakan suatu bentuk kearifan lokal, seperti misalnya paguyuban. Paguyuban berasal dari kata guyub yang artinya bersamasama. paguyuban merupakan cerminan dari kondisi interaksi pada masyarakat desa. Contohnya: di pasar, terdapat interaksi antar penjual baik yang kaya (pemilik kios) maupun yang kurang mampu (omprokan) yang menimbulakan stratifikasi sosial anatar mereka. Dengan adanya paguyuban pasar, maka tidak akan terlihat adanya stratifikasi tersebut. ketika mereka sudah bersama-sama akan mencairkan suasana. Dengan adanya paguyuban pasar, maka tidak akan terlihat adanya stratifikasi tersebut. ketika mereka 
sudah bersama-sama akan mencairkan suasananya.

Terbatas kepada rasial, tidak akan terjadi konflik jika komunikasi dalam paguyuban tersebut kuat. Paguyuban di antara suporter sepak bola merupakan bentuk interaksi sosial. Hambatan yang mungkin muncul antara lain: Pertama, Kesadaran dari diri masing-masing suporter merupakan faktor terpenting dalam upaya penghindaran konflik yakni pembentukan paguyuban. Seorang inisiator sangat diperlukan guna mengajak membentuk terlebih dahulu. Kedua, Meredam masalah yang pernah ada. Misalnya tawuran berkali-kali harus dapat dimaknai sebagai pelajaran yang dapat dipetik. Kemudian membuat kesepakatan baik secara tertulis maupun tidak tertulis untuk tidak saling mengejek suporter lawan. Ketika hal ini dicapai justru akan menimbulkan ketertarikan dari pertandingan sepak bola itu sendiri dan bahkan dapat memajukan persepakbolaan Indonesia. Ketiga, Panitia yang dapat mengakomodir kepentingan semua pihak yang terlibata dalam suatu pertandingan sepakbola. Termasuk berlaku adil terhadap supporter tuan rumah maupun supporter tim lawan.

Keempat, Sportifitas pemain harus ditumbuhkembangkan. Pemain harus bersikap fairplay dalam setiap pertandingan dan harus mau menerima apapun putusan wasit selalu pengadil dalam pertandingan. Pemain yang berbuat curang hendaknya diberi hukuman yang setimpal. Kelima, Fasilitas yang disediakan panitia pertandingan sepak bola misalnya menyediakan layar memadai diluar yang dikoneksikan dengan pertandingan yang sedang berlangsung di dalam agar para suporter yang tidak mendapat tiket masuk dapat menyaksikan pertandingan dari luar tanpa bersusah payah

Koordinator per cabang dari internal organisasi suporter juga mutlak diperlukan, kemudian koordinasi dari luar juga contohnya aparat keamanan sehingga tercipta sistem pengamanan yang kuat. Dalam pepatah, peribahasa Jawa dikenal local wisdom yang berbunyi, "Rukun agawe santosa". Artinya yakni bersatu kita teguh. "Menang tanpo ngasorake" artinya yang kalah tidak boleh menuntut kemenangan, sedangkan yang menang jangan terlalu bereuforia berlebihan. Artinya sama-sama saling menghargai.

Unsur-unsur dari paguyuban diantaranya: (1) Penyelenggara pertandingan; (2) Club atau Pemain; dan (3) Organisasi suporter. yang terpenting adalah kesadaran yang timbul dari dalam diri masing-masing pihak. Solusi untuk mewadahi adanya minat yang sama dan agar agar tidak dianggap memiliki citra buruk (ngamuk-an) maka dapat ditempuh melalui jalan Bhakti sosial dan kegiatan sosial lainnya. Karena local wisdom akan sangat sulit untuk diterapkan ketika kesadaran dalam diri masing-masing belum ada dan komunikasi yang buruk.

Selain itu, edukasi bagi suporter mutlak diperlukan juga. Seperti misalnya: memberi spanduk kedamaian, memberikan souvenir ajakan damai dan lain sebagainya. Untuk mengatasi konflik ini harus dipetakan masalahnya terlebih dahulu, siapa saja yang terlibat, tugas masing-masing pihak itu apa, tanggung jawabnya apa kemudian solusinya dapat ditemukan dengan menggali unsureunsur tersebut.

Local wisdom masyarakat jawa merupakan acuan masyarakat yang meliputi seluruh aspek kehidupan yang salah satunya berupa kata-kata bijak maupun pepatah. Ketika harus menyelesaikan konflik suporter, disemangati dengan pesan, "Rukun agawe sentosa, padu agawe bubrah". Ada pepatah, "Menang tanpa ngasorake" (Menang tanpa harus merendahkan) Menghargai dan menjaga jangan sampai melukai batin orang lain lebih diutamakan. Karena tidak seorangpun suka direndahkan. Fokus utamanya adalah penyelesaian masalah, bukan merasa menang telah mengkritik habis-habisan orang lain, sampai orang merasa tidak punya muka lagi. Bukan begitu menjadi manusia yang utama, tapi tetap rendah hati. Justru dengan rendah hati semakin dihargai dan dapat memenangkan perkara tanpa harus ada yang terluka. Inilah teknik menguasai massa termasuk massa supporter sepakbola harus lebih memafhumi local wisdom dari budaya jawa.

Dalam pandangan KRHM Satrio Hadinegoro (Kanjeng Satrio), selaku mantan Presiden Pasoepati pada Periode 2002 2004, (wawancara tanggal 21 September 2013) menyatakan bahwa ada nilai-nilai local wisdom yang dapat digunakan untuk mencegah konflik antar supporter sepak bola. Upaya-upaya dalam mencegah konflik antar supporter sepak bola adalah tergantung kepemimpinannya. Seorang pemimpin pemimpin seharusnya memahami keadaan atau karakter suporter yang diayomi. Jangan 
hanya dinilai supporter itu sebagai pendukung tim sepakbola saja. Oleh karena itu, hal tersebut harus dihargai. Jika hal ini dilihat oleh para pemimpin, mereka (supporter Pasoepati) bisa kita pegang. Jadi, pada intinya anakanak (supporter Pasoepati) itu harus di "uwongke". Dengan cara meng-uwongke (meng-orangkan) anggota Pasoepati maka secara otomatis mereka akan menuruti kata atau komando dari pimpinan atau biasa disebut Bapak Pasoepati.

Selain itu juga ada pepatah leluhur kita yaitu "menang tanpo ngasorake". Kanjeng Satrio memaknai pepatah itu, jangan kamu sombong, menang tidak boleh sombong dan kalah tidak boleh kecewa. Intinya dari pepatah itu adalah adalah bersifat ksatria. Pasoepati sifatnya lebih militan dari kader partai. Rasa memiliki Pasoepati begitu kuat. Untuk itu figur seorang "Bapak" sangat diperlukan disini, yaitu bapak yang berkharisma yang mengayomi anggotanya, agar para anggota tidak merasa hanya disepelekan saja dan kurang dihargai eksistensinya.

\section{d. Simpulan}

Faktor-faktor yang menyebabkan konflik antar suporter sepakbola dapat dikategorikan menjadi 2 (dua) faktor yakni faktor internal dan faktor eksternal. Faktor internal berasal dari dalam diri supporter diantaranya: (a)Sikap yang belum dewasanya supporter; (b) Suporter yang konsumsi minuman keras; (c) Tingkat pendidikan; (d) Sifat massa yang tersulut kemarahan akan mudah sekali diikuti teman lainnya; dan (e) Anak-anak muda yang masih menonjolkan sisi emosional dan masih labil. Adapun faktor eksternal yang berasal dari luar diri supporter, meliputi: (a) Wasit yang tidak adil; (b) Kondisi pemain; dan (c) Kondisi di lapangan seperti dendam masa lalu, gerakan spontan, saling hujat dan provokator

\section{E. Saran}

Dalam perspektif akademis, perlu dikembangkan pengintegrasian nilai-nilai local wisdom sangat penting dalam mencegah konflik antar suporter sepakbola. Nilai-nilai tersebut dapat ditanamkan kepada para suporter melalui organisasi mereka. Budaya Jawa sangat kaya dengan nilai-nilai local wisdom yang mendukung terciptanya kerukunan antar sesama termasuk antar suporter. Salah satu nilai local wisdom Jawa yang sangat relevan diterapkan kepada para suporter adalah pepatah "menang tanpa ngasorake". Pepatah ini berarti bahwa meskipun kita menang maka kita wajib menghargai dan menjaga agar pihak lawan tidak merasa dipermalukan. Apabila semua suporter menjunjung tinggi nilai ini maka niscaya gesekan antar suporter pasca pertandingan dapat ditekan. Budaya jawa yang luhur tersebut hendaknya ditanamkan pada supporter supaya mampu memunculkan kasadaran bahwa konflik supporter merupakan perbuatan terlarang yang mengganggu fair play. 


\section{daftar Pustaka}

Bambang Sugeng. 2011. Penanganan Konflik Sosial. Bandung : Pusat Kajian Bencana dan Pengungsi (PUSKASI) STKS.

Dekama. 2011. Daftar Rivalitas dan Konflik Antar Suporter di Indonesia. 27 Desember 2011. http:// dekama94.wordpress.com.

Fajar Junaedi. 2011. "Mempertanyakan Genealogi Konflik Suporter Sepakbola di Indonesia. Opini Olahraga Kompasiana," Kompas. 03 November 2011. Makalah, disajikan untuk diskusi santai sebelum nonton bareng pertandingan Indonesia vs Uruguay yang diselenggarakan oleh Komunitasi Kampus Biru UGM di Hijau Café yogyakarta 8 Oktober 2010.

J. Dwi Narwoko dan Bagong Suyanto. 2007. Sosiologi: Teks Pengantar dan Terapan. Jakarta : Kencana Prenada Media Group.

Kompas. 2012. 28 Mei.

Muamar Kadafi. 2011. "Konflik antar Suporter Sepak Bola Meruntuhkan Persatuan Dan Kesatuan Bangsa Indonesia." Skripsi. yogyakarta : S1 Teknik Informatika STMIK Amikom.

Mukti Fajar Nur Dewata dan yulianto Achmad. 2010. Dualisme Penelitian hukum Normatif dan Empiris. yogyakarta : Pustaka Pelajar.

Neuman, William L. 2006. Social Research Methods, Qualitative and Quantitative Approaches, Sixth Edition. USA: Pearson.

Pheni Chalid. 2005. Otonomi Daerah: Masalah, Pemberdayaan, dan Konflik, Jakarta : Kemitraan.

Solopos. 2013, 5 Sepetember.

Sulistyowati Irianto dan Shidarta. 2009. Metode Penelitian Hukum: Konstelasi dan Refleksi. Jakarta : yayasan Obor Indonesia 